\title{
Donor Cell Composition and Reactivity Predict Risk of Acute Graft-versus-Host Disease after Allogeneic Hematopoietic Stem Cell Transplantation
}

\author{
Darius Sairafi, ${ }^{1}$ Arwen Stikvoort, ${ }^{1,2}$ Jens Gertow, ${ }^{2}$ Jonas Mattsson, ${ }^{1,2}$ and Michael Uhlin ${ }^{2,3}$ \\ ${ }^{1}$ Centre for Allogeneic Stem Cell Transplantation, Karolinska University Hospital, Huddinge, Sweden \\ ${ }^{2}$ Department of Oncology and Pathology, Karolinska Institutet, Stockholm, Sweden \\ ${ }^{3}$ Department of Clinical Immunology and Transfusion Medicine, Karolinska University Hospital, Huddinge, Sweden
}

Correspondence should be addressed to Darius Sairafi; darius.sairafi@ki.se and Arwen Stikvoort; arwen.stikvoort@ki.se

Received 30 June 2016; Revised 13 September 2016; Accepted 29 September 2016

Academic Editor: Stuart Berzins

Copyright (C) 2016 Darius Sairafi et al. This is an open access article distributed under the Creative Commons Attribution License, which permits unrestricted use, distribution, and reproduction in any medium, provided the original work is properly cited.

\begin{abstract}
Background. Graft-versus-host disease (GVHD) is a serious complication after allogeneic hematopoietic stem cell transplantation (HSCT). We designed a functional assay for assessment of individual risk for acute GVHD. Study Design and Methods. Blood samples were collected from patients and donors before HSCT. Two groups of seven patients each were selected, one in which individuals developed acute GVHD grades II-IV and one in which none showed any clinical signs of GVHD. Peripheral blood mononuclear cells (PBMCs) isolated from donors were incubated in mixed lymphocyte cultures (MLCs) with recipient PBMCs. The cells were characterized by flow cytometry before and after MLC. Results. Samples from donors in the GVHD group contained significantly lower frequencies of naïve $\gamma \delta$ T-cells and T-cells expressing NK-cell markers CD56 and CD94. Donor samples in this group also exhibited lower frequencies of naïe $\mathrm{CD}^{+} 5^{+} \mathrm{T}$-cells compared to controls. After MLC, there were dissimilarities in the CD4/CD8 T-cell ratio and frequency of $\mathrm{CD} 69^{+} \mathrm{T}$-cells between the two patient groups, with the non-GVHD group showing higher frequencies of $\mathrm{CD}^{+}$and $\mathrm{CD} 9^{+} \mathrm{T}$-cells. Conclusion. We conclude that a thorough flow cytometric analysis of donor cells for phenotype and allogeneic reactivity may be of value when assessing pretransplant risk for severe acute GVHD.
\end{abstract}

\section{Introduction}

Although an established treatment, allogeneic hematopoietic stem cell transplantation (HSCT) is associated with several serious side effects. These are generally grouped into three categories: infectious complications, drug toxicity, and graftversus-host disease (GVHD).

GVHD manifests in an acute and chronic form, each with distinct clinical signs and symptoms. Although both are caused by an immunological reaction between donor-derived lymphocytes and recipient tissue, the pathophysiological mechanisms involved are different [1].

Acute GVHD usually occurs within the first three months after engraftment and it has a more rapid course. The main effector cells are donor T-cells that are transferred with the graft and become activated in response to a proinflammatory milieu and differences in cell-surface antigens. It has been shown that naïve $\mathrm{CD} 4^{+}$T-cells may have a particularly important role in the initiation of the GVHD process [2]. Activation of these cells by host-specific antigens elicits an immunological reaction directed against host tissue resulting in local and systemic inflammation. Acute GVHD is also associated with an increased level of immunodeficiency, both directly through the immune-modulatory effect of the ongoing inflammatory process [3] and indirectly due to the immunosuppressive agents used for treatment of this potentially life-threatening condition [4].

With today's methods of tissue typing, it is possible to obtain a high level of matching between donor and recipient regarding major histocompatibility antigens (MHC). Even though this progress has significantly improved the outcome of HSCT, the incidence of acute GVHD has still been as high as $80 \%$ in some reports [5]. One reason for this is thought to be the existence of so-called minor histocompatibility antigens. These are polymorphic, non-MHC genes, the end products of which may cause an alloreaction [6]. 
Severe acute GVHD is often resistant to treatment, and it is a widely accepted consensus that preventive measures significantly improve the chances of a positive outcome, as compared to efforts to treat established disease. For this purpose, a predictive test for GVHD would be of great clinical value, particularly because overtreatment with immunosuppressive agents in itself is associated with serious complications $[7,8]$. With today's methods, there is no reliable way of predicting the risk of GVHD with any certainty. The aim of this project was to design a functional in vitro test for assessment of pretransplant risk for acute GVHD.

\section{Material and Methods}

2.1. Patients and Donors. 29 patients and their corresponding sibling donors gave their informed consent and were included in the current study. Inclusion criteria for the study were a HLA matched sibling donor and PBSC as stem cell source, and the apheresis was performed at Karolinska University Hospital. All aspects of this study were reviewed and approved by the regional Ethical Committee in Stockholm (approval number 2008/206-31). Blood samples were collected from patients immediately before the start of conditioning therapy and from the donors in conjunction with harvesting of the peripheral blood stem cell (PBSC) graft. We selected seven recipient/donor pairs where the patients had developed acute GVHD of grades II-IV, within the first three months after HSCT, with manifestation in the skin and the gastrointestinal (GI) tract, with or without liver involvement. Seven control cases were selected from those who had had no signs of GVHD and who had not received any additional immunosuppressive therapy apart from the standard GVHD prophylaxis. The remaining 15 patient/donor pairs were excluded from further studies due to established or suspected acute GVHD grade I. Grading of GVHD was performed according to the Glucksberg criteria [9]. All cases of isolated GI-GVHD were verified by biopsies. All recipients and their sibling donors were tissue-typed by allele-level PCR with sequence-specific primers [10]. Patientdonor pairs were matched regarding HLA-A, HLA-B, HLAC, HLA-DP, HLA-DQ, and HLA-DR. Details concerning patient characteristics and treatments are given in Table 1. No statistical differences could be observed between the groups for the parameters shown in Table 1.

2.2. Antibodies. Fluorescein isothiocyanate (FITC)-, phycoerythrin (PE)-, allophycocyanin (APC)-, BD Horizon ${ }^{\mathrm{TM}} \mathrm{V} 450$ (V450)-, and PE-Cy5-labelled anti-CD3 (UCHT1); APC-labelled anti-CD27 (L128); FITC-labelled anti-CD19 (HIB19); APC-labelled anti-CD45RO (UCHL1); APC-labelled antiCD19 (HIB19); FITC-labelled anti-CD56 (MCAM16·2); Alexa Fluor $^{\circledR} 700$-labelled anti-CD4 (RPA-T4); APC-Cy ${ }^{\mathrm{TM}}$ 7-labelled anti-CD8 (SK1); APC-Cy ${ }^{\mathrm{TM}} 7$-labelled anti-CD69 (FN50); FITC-labelled anti-CD95 (DX2); PE-Cy7-labelled anti-CD3 (SK7); PE-labelled anti-CD45RA (HI100); FITC-labelled anti-CD28 (CD28.2); FITC-labelled anti-CD94 (HP-3D9); FITC-labelled anti-T-cell receptor (TCR) $\alpha \beta$ (WT31); PE-labelled anti-TCR $\alpha \beta$ (T10B9.1A-31); FITC-labelled anti-CD69 (FN50); PE-Cy7-labelled anti-CCR7 (3D12); BD Horizon ${ }^{\mathrm{TM}}$
V500 (V500)-labelled anti-CD8 (RPA-T8); and 7-aminoactinomycin D (7-AAD) were purchased from BD Biosciences (Franklin Lakes, NJ). Pacific Blue ${ }^{\mathrm{TM}}$-labelled antiCD107a (LAMP-1) was purchased from Biolegend (San Diego, CA). PE-labelled anti-TCR $\gamma \delta$ (B1.1) was purchased from eBioscience (San Diego, CA). FITC-labelled anti-TCR pan $\gamma \delta$ (IMMU510) was purchased from Beckman Coulter (Fullerton, CA). Pacific Orange-labelled anti-CD8 (3B5) was purchased from Invitrogen (Camarillo, CA).

2.3. Mixed Lymphocyte Culture. PBMCs were isolated from peripheral blood samples using density-gradient centrifugation $(800 \times$ g, $20 \mathrm{~min}$; Rotina 420 [Hettich, Beverly, MA, USA] with Lymphoprep [Fresenius Kabi, Oslo, Norway]). They were then cryopreserved at $-196^{\circ} \mathrm{C}$ with $10 \%$ DMSO in complete RPMI-1640 medium (Hyclone ${ }^{\circledR}$ [Thermo Fisher Scientific Inc., Waltham, MA, USA] enriched with 10\% human AB-serum [Karolinska University Hospital] and $100 \mathrm{mg} / \mathrm{mL}$ streptomycin [Gibco, Life Technologies, Paisley, UK]). Donor PBMCs were used as responders in this experiment. The method has been described in detail previously [11]. Briefly, the cells were incubated with $1 \mu \mathrm{M}$ carboxyfluorescein succinimidyl ester (CFSE; Molecular Probes, Inc. [Thermo Fisher]) in $\mathrm{PBS}$ and incubated in $37^{\circ} \mathrm{C}$ for 10 minutes. The reaction was blocked with PBS containing 10\% ABserum, after which the cells were washed and resuspended in complete RPMI-1640 medium in flat-bottomed 6-well plates at $1 \times 10^{6}$ cells $/ \mathrm{mL}$. PBMCs from the corresponding recipients were used as stimulator cells after irradiation with $30 \mathrm{~Gy}$. Responder and stimulator cells were added to the wells in a responder : stimulator ratio of $5: 1$. As controls, we used responder cells that were either untreated, CFSE-stained in complete medium alone, or CFSE-stained in complete medium with $10 \mu \mathrm{g} / \mathrm{mL}$ phytohemagglutinin A (PHA; SigmaAldrich, St. Louis, MO, USA). The plates were incubated at $37^{\circ} \mathrm{C}$ in an atmosphere of $5 \% \mathrm{CO}_{2}$ for 6 days, after which the cells were harvested, stained, and analysed by flow cytometry. Supernatant from each well was collected and stored at $-20^{\circ} \mathrm{C}$ for later analysis.

2.4. Flow Cytometry. Cell-surface staining of thawed, unmanipulated donor PBMCs and responder cells from each MLC condition was performed as described previously [12]. Briefly, cells were incubated with the specified antibodies in PBS for $20 \mathrm{~min}$ at $4^{\circ} \mathrm{C}$, washed twice in PBS, and incubated with 7-AAD for $15 \mathrm{~min}$ at room temperature. Stained cells were analysed on a Beckman Coulter Gallios using Beckman Coulter Gallios acquisition software (Beckman Coulter Inc., Fort Collins, CO) or the BD FACS Canto using BD FACS Diva software (BD Biosciences). The data acquired was analysed with FlowJo software (Tree Star Inc., Ashland, OR). Cells were gated according to fluorescence-minus-one (FMO) samples, which were included in each experiment. Lymphocytes were distinguished from monocytes by their side- and forwardscatter phenotype.

2.5. Multiplex Assay. Supernatant samples were analysed for the levels of 26 different cytokines (Eotaxin, G-CSF, GM-CSF, IFN- $\alpha 2$, IFN- $\gamma$, IL-10, IL-12 (p40), IL-12 (p70), IL-13, IL-15, 
TABLE 1: Patient and donor characteristics.

\begin{tabular}{|c|c|c|}
\hline Criteria & Group 1 (non-GVHD) & Group 2 (GVHD) \\
\hline Patients, $n$ & 7 & 7 \\
\hline \multicolumn{3}{|l|}{ Recipient } \\
\hline Age at HSCT (median (range)) & $47(30-58)$ & $51(36-64)$ \\
\hline Gender, $n$ (female/male) & $3 / 4$ & $3 / 4$ \\
\hline \multicolumn{3}{|l|}{ Diagnosis, $n$} \\
\hline AML & 1 & 3 \\
\hline ALL & 2 & 0 \\
\hline CLL & 1 & 0 \\
\hline MDS/MPD & 3 & 2 \\
\hline Solid tumour & 0 & 2 \\
\hline \multicolumn{3}{|l|}{ Donor } \\
\hline HLA-identical sibling, $n$ & 7 & 7 \\
\hline Age at HSCT (median (range)) & $40(31-67)$ & $54(43-68)$ \\
\hline \multicolumn{3}{|l|}{ Conditioning regimen, $n$} \\
\hline $\mathrm{Cy}+\mathrm{fTBI}$ & 2 & 0 \\
\hline $\mathrm{Cy}+\mathrm{Bu}$ & 2 & 4 \\
\hline $\mathrm{Flu}+\mathrm{Bu}$ & 2 & 1 \\
\hline $\mathrm{Flu}+\mathrm{Cy}$ & 0 & 2 \\
\hline $\mathrm{Cy}+\mathrm{fTBI}+\mathrm{Flu}$ & 1 & 0 \\
\hline \multicolumn{3}{|l|}{ Antithymocyte treatment, $n$} \\
\hline ATG & 1 & 0 \\
\hline Campath & 1 & 0 \\
\hline \multicolumn{3}{|l|}{ GVHD prophylaxis, $n$} \\
\hline CsA + MTX & 7 & 5 \\
\hline FK + RAPA & 0 & 2 \\
\hline \multicolumn{3}{|l|}{ Graft source, $n$} \\
\hline PBSCs & 7 & 7 \\
\hline \multicolumn{3}{|l|}{ Cell dose, median (range) } \\
\hline Total nucleated cells $\left(\times 10^{8} / \mathrm{kg}\right)$ & $8.6(7.5-21.6)$ & $14.8(5.0-24.5)$ \\
\hline $\mathrm{CD} 4^{+}$cells $\left(\times 10^{6} / \mathrm{kg}\right)$ & $8(4.7-11)$ & $9.1(4.3-9.6)$ \\
\hline
\end{tabular}

AML, acute myeloid leukaemia; ALL, acute lymphoblastic leukaemia; ATG, anti-T-cell globulin; Bu, busulfan; CLL, chronic lymphocytic leukaemia; CsA, cyclosporine A; Cy, cyclophosphamide; FK, tacrolimus; Flu, fludarabine; fTBI, fractionated total body irradiation; GVHD, graft-versus-host disease; HLA, human leukocyte antigen; MDS, myelodysplastic syndrome; MPD, myeloproliferative disorders; MTX, methotrexate; $n$, number; PBSC, peripheral blood stem cell; RAPA, sirolimus. Statistical analysis was done with the Mann-Whitney $U$ test and Fisher's exact test.

IL-17, IL-1 $\alpha$, IL-1 $\beta$, IL-2, IL-3, IL-4, IL-5, IL-6, IL-7, IL-8, IP10, MCP-1, MIP- $1 \alpha$, MIP- $1 \beta$, TNF- $\alpha$, and TNF- $\beta$ ). The MILLIPLEX MAP Human Cytokine/Chemokine-Premixed 26 Plex from Millipore [Millipore Corporation, Temecula, CA, USA] was performed according to manufacturer's protocol and as described before [13-15]. The Luminex IS 2.3 software [Luminex Corp., Austin, TX, USA] on the LABScan100 (One Lambda Inc., Canoga Park, CA, USA) was used for analysis.

2.6. Statistical Analysis. Data was analysed and displayed using GraphPad Prism software (GraphPad Software Inc., San Diego, CA) and IBM SPSS Statistics 23 software (IBM, Armonk, NY, USA). Levels and changes in cell-surface markers and levels of soluble factors were compared between the non-GVHD and GVHD groups. The following markers were studied on unmanipulated donor PBMCs: CD3, CD4, CD8, CCR7, CD45RA, CD45RO, CD28, CD69, CD94, CD56, TCR $\alpha \beta, \operatorname{TCR} \gamma \delta, \mathrm{CD} 95, \mathrm{CD} 19$, and CD27. Responder cells after MLC were analysed for CD3, CD4, CD8, TCR $\alpha \beta$,
TCR $\gamma \delta$, CD45RO, CCR7, CD69, and CD107a. Nonparametric comparisons were performed using the Mann-Whitney $U$ test (Table 1; Figures 1-3) and Fisher's exact test (Table 1). Due to sample size limitations, no multivariate analyses were performed. Data are presented as median percentages or as absolute numbers. The number of samples per group is seven unless stated otherwise.

\section{Results}

3.1. Properties of Unmanipulated Donor Cells. PBMCs from unmanipulated donor samples were stained for flow cytometric analysis. Acquired phenotypic data were subsequently divided into the two groups "non-GVHD" $(n=7)$ and "GVHD” $(n=7)$ based on patient characteristics after transplantation and analysed for possible differences.

There was no significant difference between the nonGVHD group and the GVHD group regarding frequencies of major lymphocyte populations, that is, total T-cells (median 

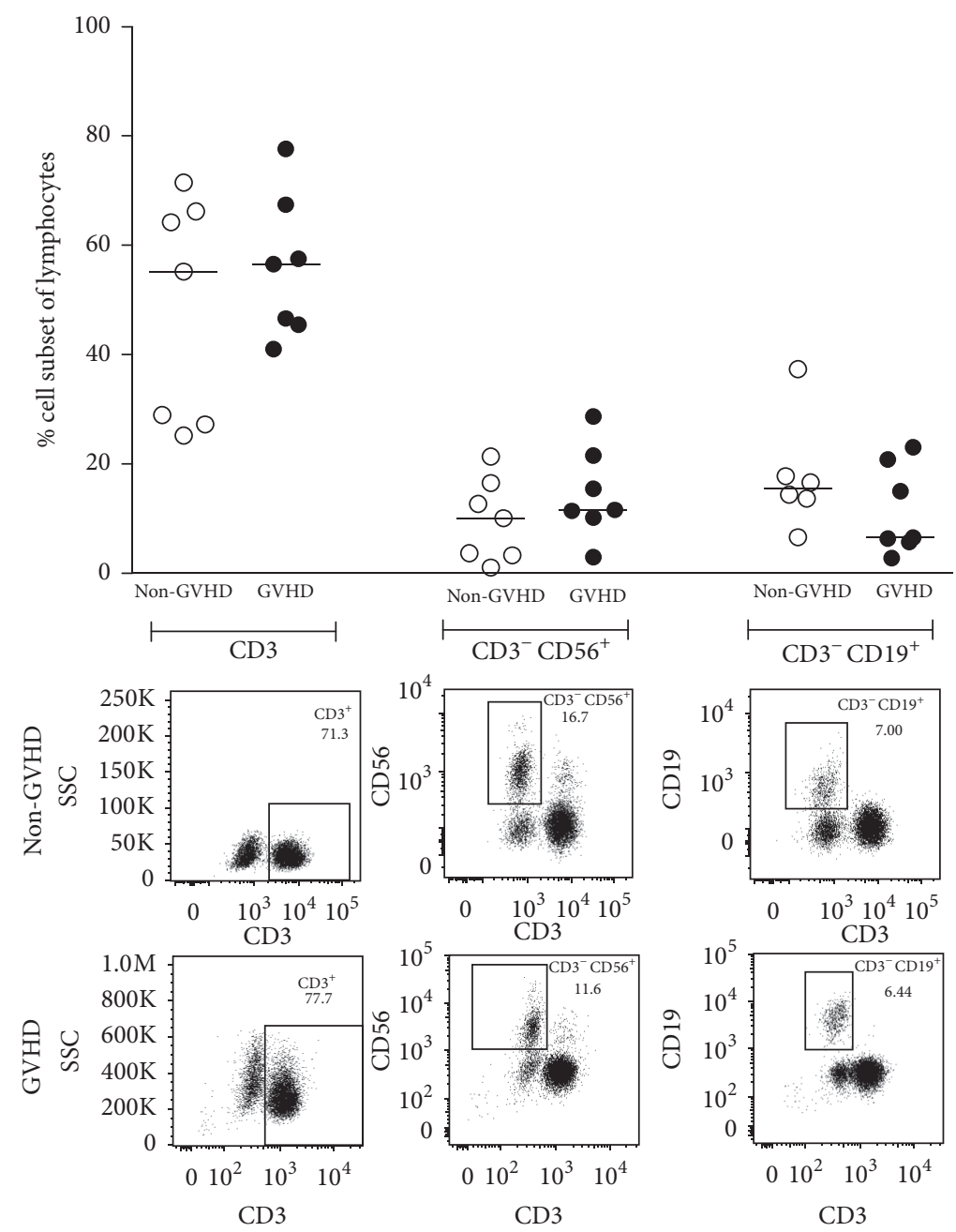

(a)
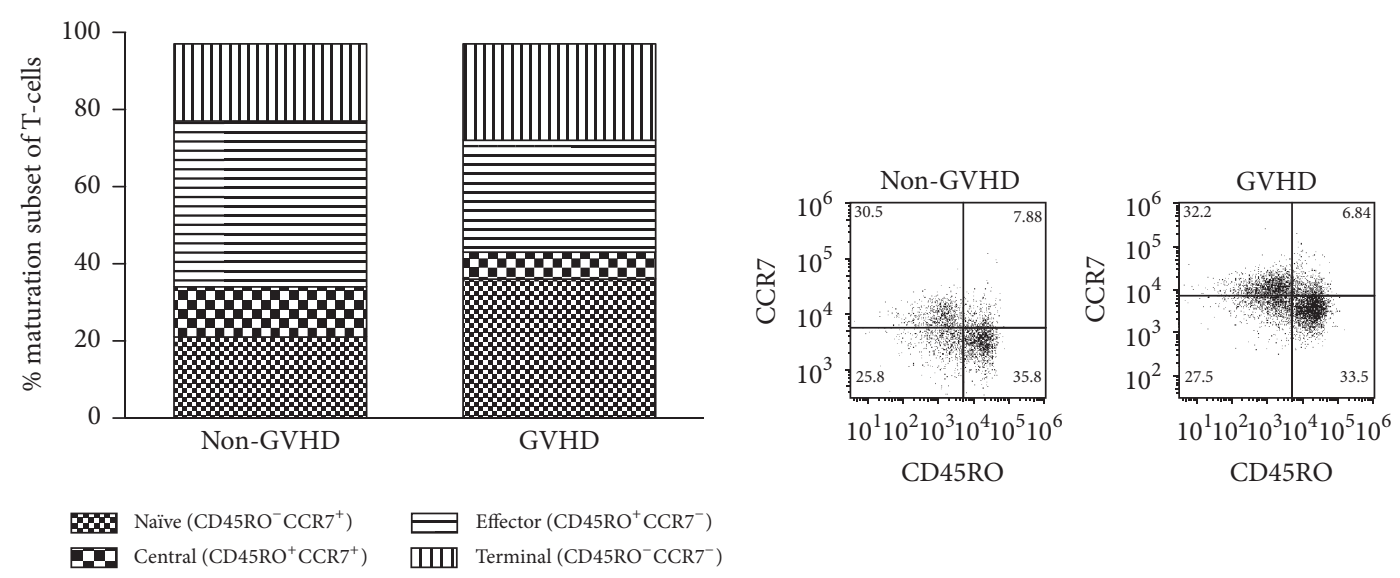

(b)

FIGURE 1: No significant differences between the non-GVHD and GVHD groups regarding major lymphocyte subsets or T-cell maturation subsets in unmanipulated donor samples. Flow cytometry-acquired phenotypic data analysed in blood samples from donors. The data were divided into two groups based on if patients did or did not develop acute GVHD grades II-IV. Each dot represents the cell-subset frequency of one donor and horizontal bars indicate the median of each group. Representative FACS plots are shown below each dot-plot of one non-GVHD and one GVHD patient. (a) Percentages of total T-cells $\left(\mathrm{CD}^{+}\right)$, NK-cells $\left(\mathrm{CD}^{-} \mathrm{CD}^{+} 6^{+}\right)$, and B-cells $\left(\mathrm{CD} 3^{-} \mathrm{CD} 19^{+}\right)$. No differences were observed for these cellular subsets between the non-GVHD and GVHD patient groups. (b) Proportions of T-cell subsets at different maturation states in the total T-cell population, expressed as median percentages. Terminal, terminally differentiated T-cells $\left(\mathrm{CD}_{5} \mathrm{RO}^{-} \mathrm{CCR7}^{-}\right)$; effector, effector memory T-cells $\left(\mathrm{CD} 45 \mathrm{RO}^{+} \mathrm{CCR7}^{-}\right)$; central, central memory T-cells $\left(\mathrm{CD}^{2} 5 \mathrm{RO}^{+} \mathrm{CCR}^{+}\right)$; naïve, naïve T-cells $\left(\mathrm{CD} 45 \mathrm{RO}^{-} \mathrm{CCR}^{+}\right)$. No differences were observed. 


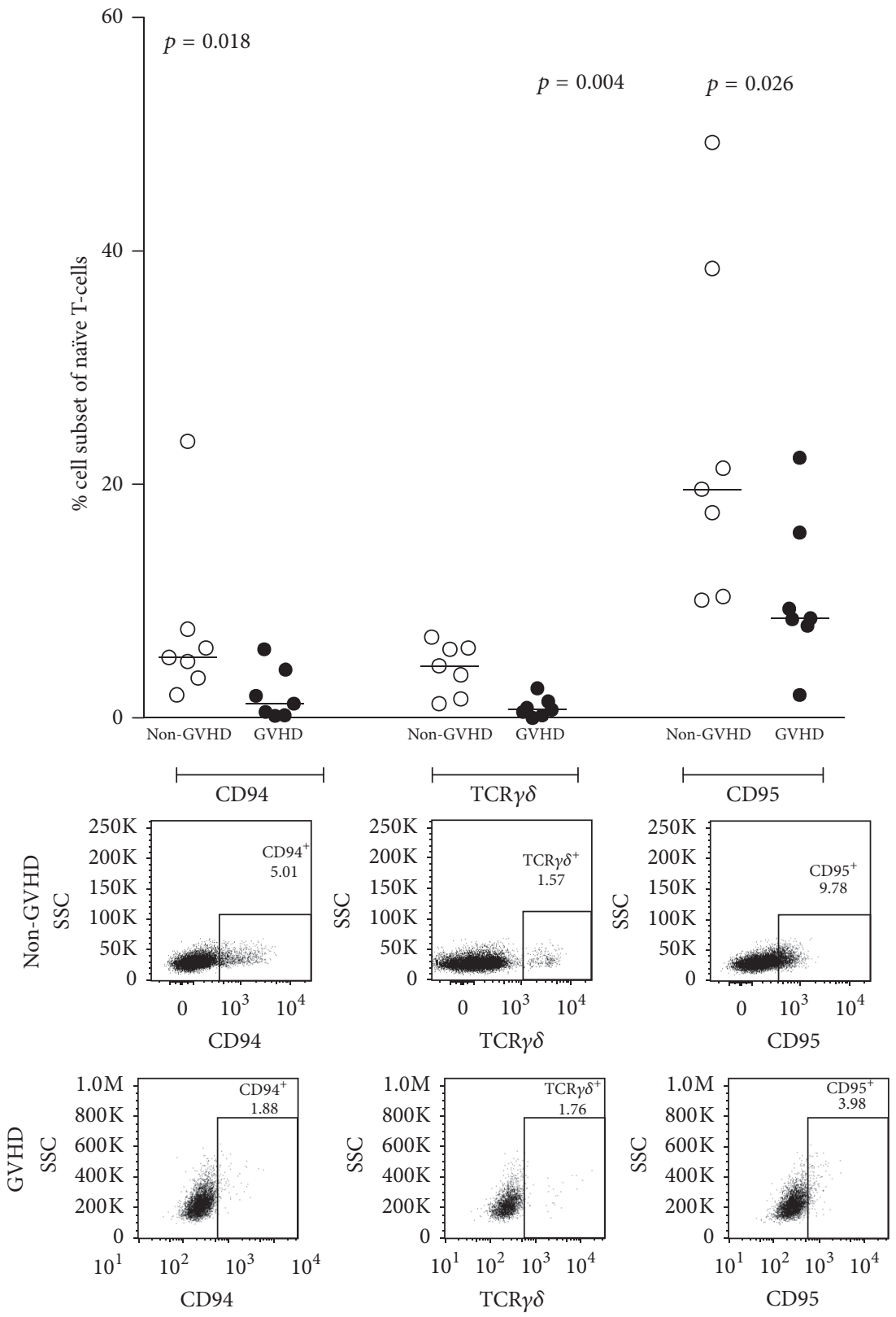

(a)
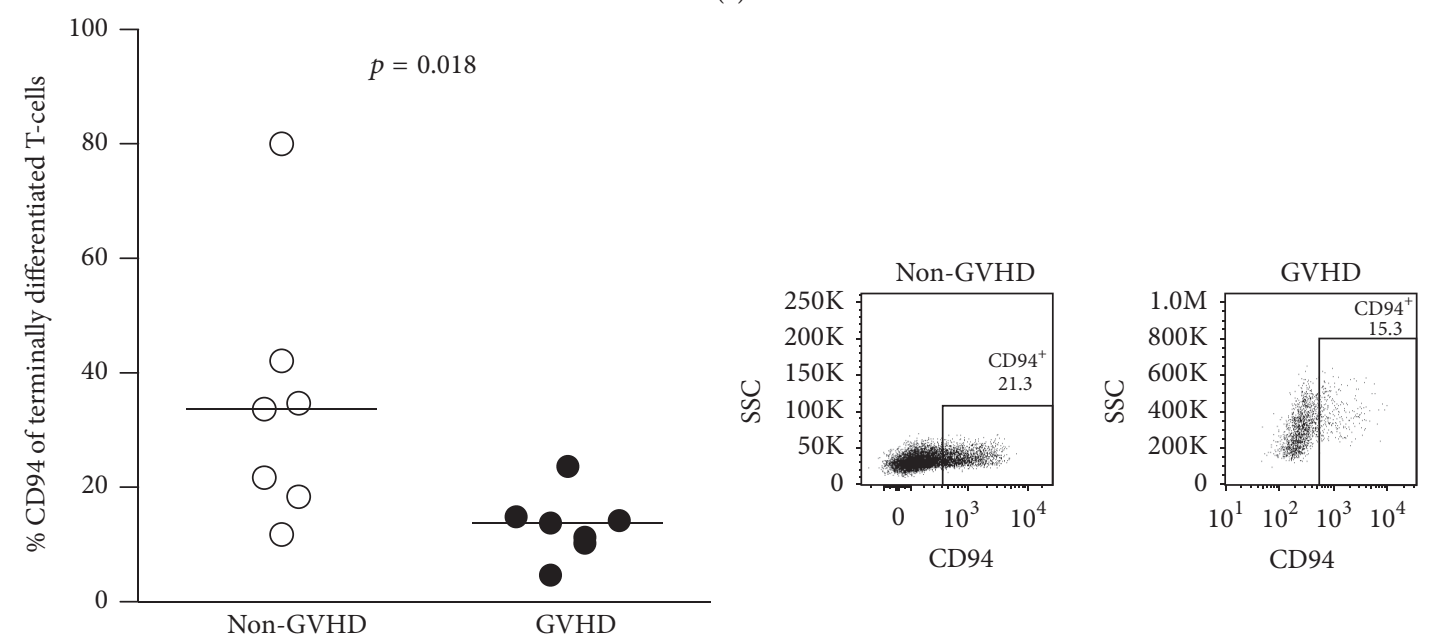

(b)

FIgure 2: Continued. 


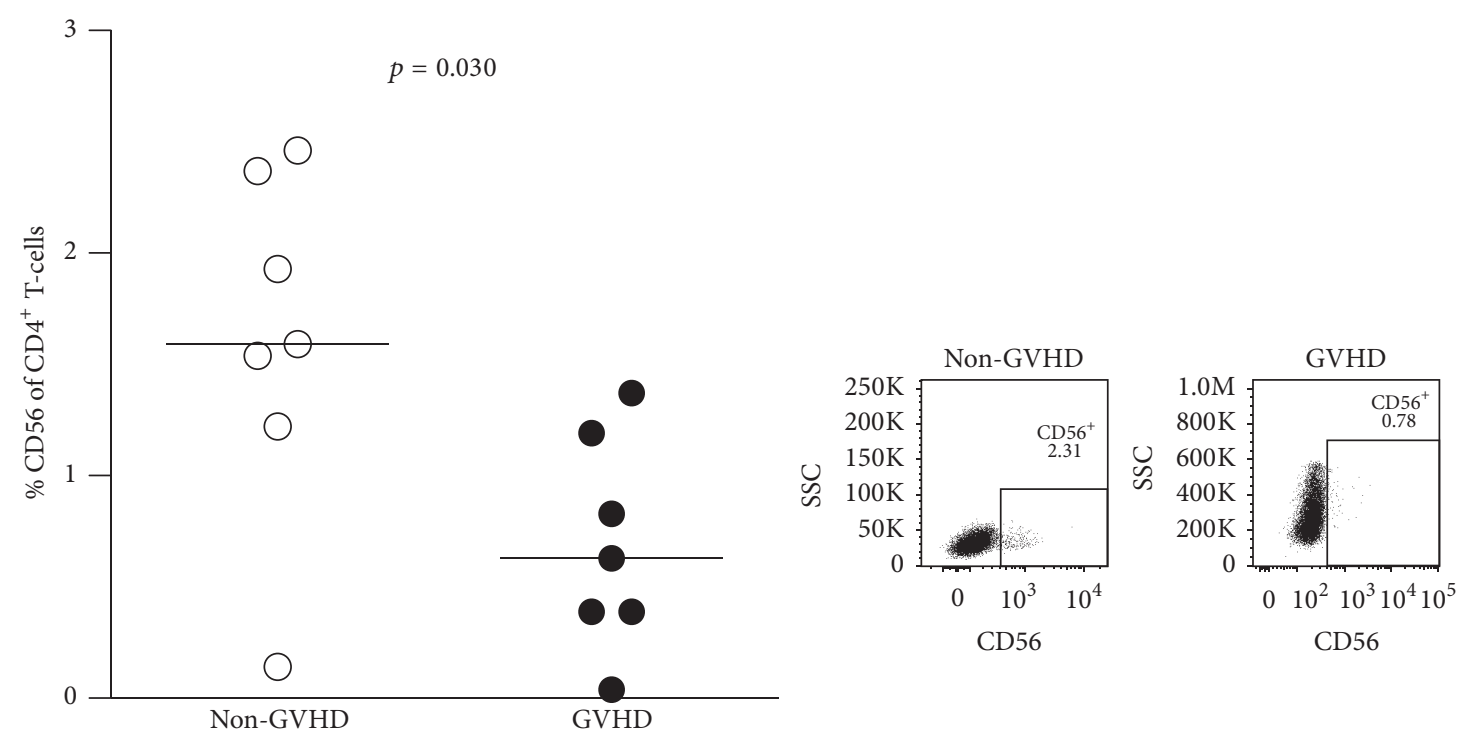

(c)

FIGURE 2: The non-GVHD group had higher frequencies of CD94 $4^{+}, \mathrm{TCR} \gamma \delta^{+}, \mathrm{CD} 56^{+}$, and $\mathrm{CD} 95^{+} \mathrm{T}$-cell subsets than the GVHD group in unmanipulated donor samples. Each dot represents the cell-subset frequency of one donor and horizontal bars indicate the median of each group. Representative FACS plots are shown below each dot-plot of one non-GVHD and one GHVD patient. Statistical analysis was done with the Mann-Whitney $U$ test. (a) Percentages of CD $94^{+}$, TCR $\gamma \delta^{+}$, and CD95 $5^{+}$naive T-cells were increased within the non-GVHD group. (b) CD94 was expressed to a higher degree on terminally differentiated T-cells within the non-GVHD group. (c) Percentages of CD56 ${ }^{+}$CD $4^{+}$ T-cells were increased within the non-GVHD group.

$55.2 \%$ versus $56.6 \% ; p=0.535$ ), NK-cells (median $10.1 \%$ versus $11.6 \% ; p=0.383)$, or B-cells (median $15.5 \%(n=6)$ versus $6.5 \% ; p=0.295$ ) (Figure $1(\mathrm{a})$ ).

In order to examine the maturation status of T-cells in the grafts, we used the surface markers CD45RO and CCR7. The distribution of the different memory subsets of total Tcells in the two groups is shown in Figure 1(b). No statistically significant differences between the non-GVHD and the GVHD groups were found regarding frequencies of naïve $\left(\mathrm{CD} 45 \mathrm{RO}^{-} \mathrm{CCR7}^{+}\right.$; median $22.1 \%$ versus $43.3 \%$; $\left.p=0.165\right)$, central memory $\left(\mathrm{CD}^{2} 5 \mathrm{RO}^{+} \mathrm{CCR}^{+}\right.$; median $12.6 \%$ versus $8.7 \%$; $p=0.306)$, effector memory $\left(\mathrm{CD} 45 \mathrm{RO}^{+} \mathrm{CCR7}^{-}\right.$; median $35.9 \%$ versus $28 \%$; $p=0.259$ ), or terminally differentiated T-cells $\left(\mathrm{CD} 45 \mathrm{RO}^{-} \mathrm{CCR}^{-}\right.$; median $21.7 \%$ versus $18.3 \%$; $p=0.620$ ). Additionally, no significant differences were seen between the two categories of donors when we analysed total frequencies of $\mathrm{CD}^{+}$and $\mathrm{CD}^{+}$T-cells or their individual maturation status.

TCR $\gamma \delta$-chains are expressed by a minor population of Tcells [16]. The non-GHVD group had a higher frequency of total TCR $\gamma \delta^{+}$naïve memory T-cells than the GVHD group (median $4.5 \%$ versus $0.7 \%$; $p=0.004$ ) (Figure $2(\mathrm{a})$ ).

After activation, T-cells transiently express certain NKcell markers [17]. In this material, CD $94^{+}$total T-cells were found in higher frequencies in the non-GVHD group for naïve memory T-cells (median $5.2 \%$ versus $1.2 \%$; $p=0.018$; Figure 2(a)) and for terminally differentiated T-cells (median $33.7 \%$ versus $13.8 \%$; $p=0.018$; Figure $2(\mathrm{~b})$ ) as compared to the GVHD group. Similarly, CD56 expression on $\mathrm{CD} 4^{+}$ T-cells was found at higher frequencies in the non-GVHD group (median $1.6 \%$ versus $0.6 \% ; p=0.030$ ) (Figure $2(c)$ ).
T-cells expressing the Fas receptor CD95 were observed at significantly higher frequencies in the non-GVHD group in naïve memory T-cells (median $19.6 \%$ versus $8.55 \% ; p=0.026$; Figure 2(a)) as compared to the GVHD group.

3.2. Mixed Lymphocyte Reaction. To evaluate the alloreactive capacity of donor lymphocytes towards recipient cells, a mixed lymphocyte culture (MLC) was performed. By using a multicolor flow cytometry panel, we wanted to detect changes in frequencies of lymphocyte subpopulations of the responding cells and their surface expression of the activation markers CD69 and CD107a after MLC. Ultimately, we wanted to determine whether any changes correlated to the incidence of acute GVHD.

As illustrated in Figure 3(a), no differences in total T-cell percentages could be observed between the patient groups for all three MLC conditions. There was a change in the proportions of $\mathrm{CD}^{+}$and $\mathrm{CD}^{+}$T-cells after MLC when we compared the two patient groups. Before the MLC, the CD4/CD8 ratio in both groups was comparable (non-GVHD 1.44 versus GVHD 1.9; $p=0.165$; Figure 3(b)). At day 6 , the CD4/CD8 ratio had changed in the 5:1 stimulated samples (non-GVHD 1.02 versus GVHD 3.36; $p=0.052$ ) and PHA stimulated samples (non-GVHD 0.30 versus GVHD $1.33 ; p=$ 0.038). In both settings, the CD4/CD8 ratio skewed towards an increased proportion of $\mathrm{CD} 4^{+} \mathrm{T}$-cells in the GVHD group as compared to the non-GVHD group (Figure 3(b)).

The frequencies of T-cells positive for early activation marker CD69 were comparable between the two patient groups before MLC (median non-GVHD 4\% versus GVHD $6.3 \% ; p=1.0$ ). However, expression of CD69 was higher 


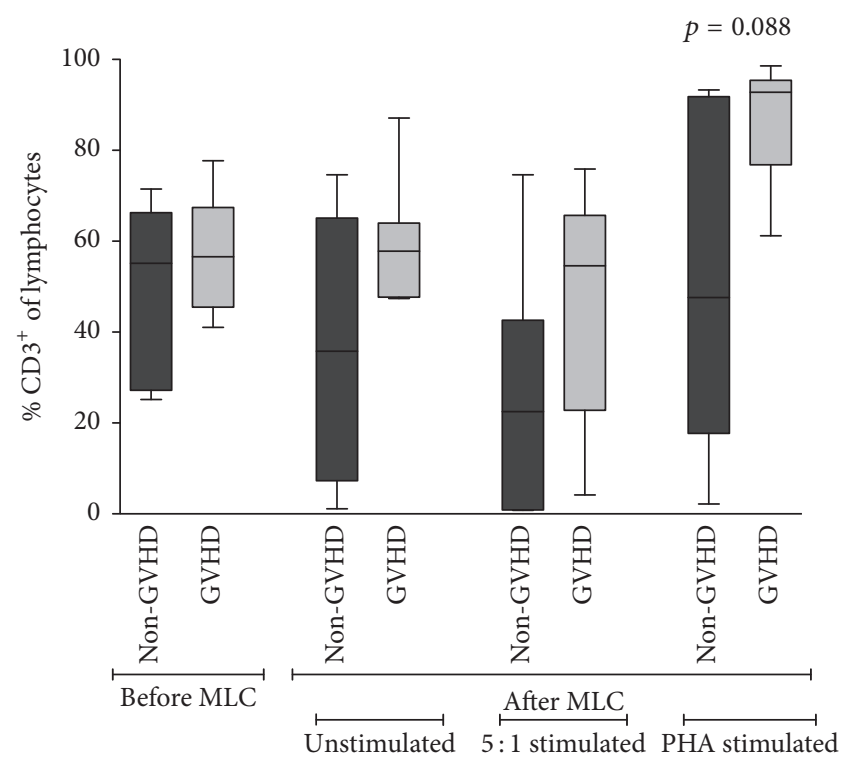

(a)

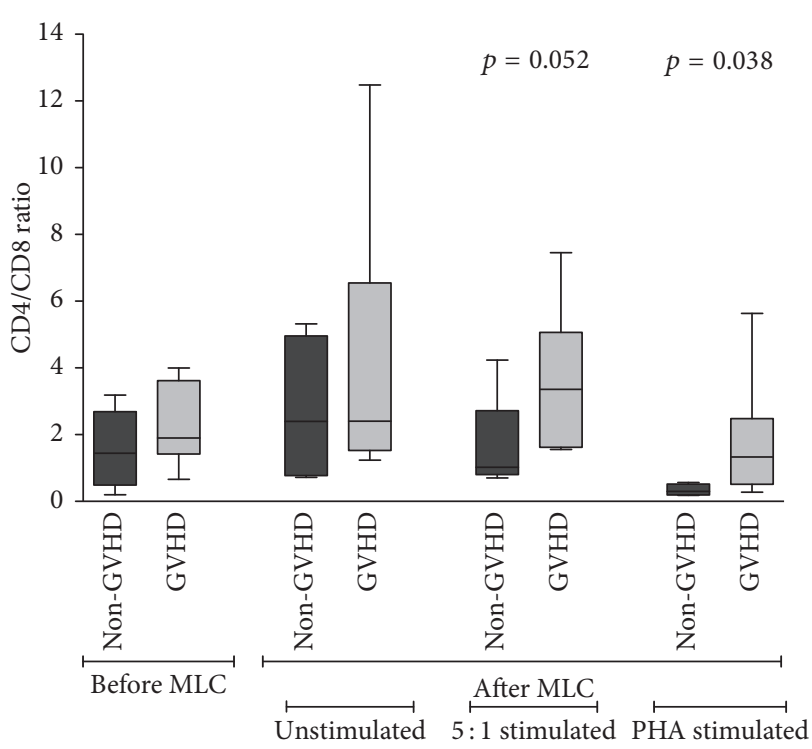

(b)

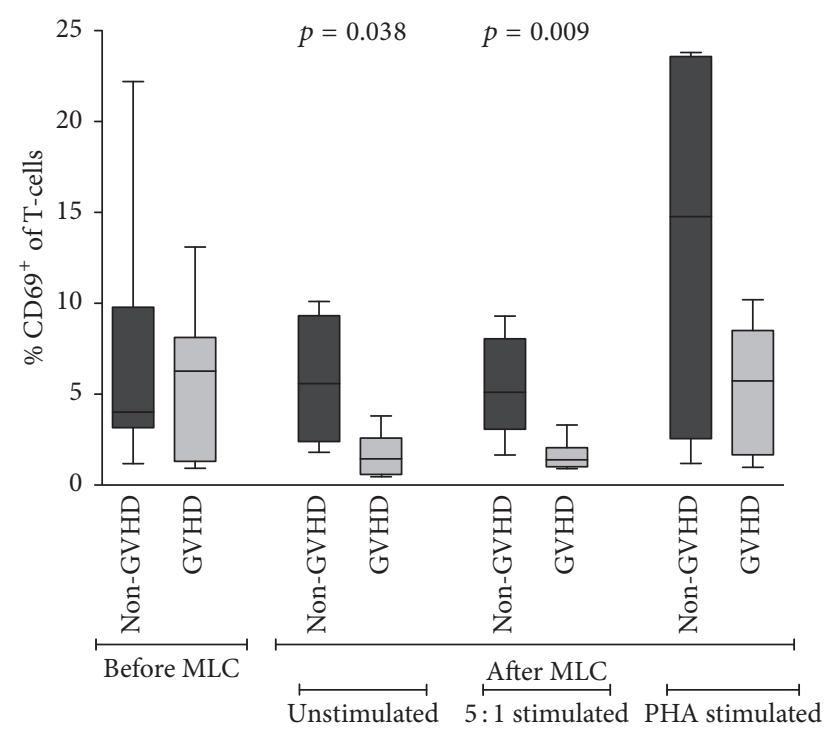

(c)

Figure 3: The GVHD group showed dissimilarity in CD4/CD8 T-cell ratios and frequencies of CD69 $9^{+}$T-cells when responding donor cells were analysed after MLC. Flow cytometric analysis of responder cells (of donor origin) before and after MLC. Statistical analysis was done with the Mann-Whitney $U$ test. (a) Frequencies of T-cells before and after MLC. T-cell frequencies did not differ between the non-GVHD and GVHD groups. (b) CD4/CD8 T-cell ratios before and after MLC. The CD4/CD8 T-cell ratio was similar between the two patient groups before MLC. After MLC, the CD4/CD8 ratio shifted towards an increase of CD $4^{+}$T-cells and a decrease of CD8 ${ }^{+}$T-cells in the GVHD group. (c) Frequencies of $\mathrm{CD} 9^{+}$T-cells before and after MLC. CD69 was expressed more on T-cells of non-GVHD patients after MLC for the unstimulated and $5: 1$ stimulated condition.

for total T-cells in the non-GVHD group than in the GHVD group after an unstimulated 6-day incubation (median 5.6\% $(n=4)$ versus $1.5 \%(n=6) ; p=0.038)$ and after the $5: 1$ stimulated MLC condition (median $5.1 \%(n=5)$ versus $1.4 \%$ $(n=6) ; p=0.009$; Figure 3(c)). No difference was seen between the two patient groups in $\mathrm{CD} 9^{+} \mathrm{T}$-cell frequencies after 6-day incubation with PHA.

There was no significant difference in cytokine concentrations in the supernatant of all three conditions after MLC between the two patient groups (data not shown).
Additionally, no difference in cell proliferation as measured by CFSE could be observed (data not shown).

\section{Discussion}

Most studies on the effect of graft composition on outcome after HSCT have focused on quantitative differences in doses of total nucleated cells, CD $34^{+}$cells, and T-cells. However, there have been reports indicating that frequencies of minor cell subsets and phenotypic distinctions within these 
populations could be connected to the alloreactive potential of the graft and may therefore affect clinical outcome [18-25].

In our study we wanted to use multicolor flow cytometry to detect potential differences in frequencies of lymphocyte subsets in donor material before and after in vitro MLC in order to predict severe GVHD development. We aimed at creating a robust test that could be used in a potential clinical routine environment. As clinicians and researchers in the field know that grade I acute GVHD can easily be misdiagnosed, we only included patients without any signs of GVHD or with grade II-IV acute GVHD (Table 1). Our results illustrate that flow cytometry on graft material using the most common phenotypic markers is not enough to detect predictive markers for GVHD (Figure 1). Today's use of flow cytometers with $>2$ lasers in clinical routine enables more in-depth graft analysis.

The biological functions of T-cells that express the $\gamma \delta \mathrm{T}$ cell receptor $(\gamma \delta \mathrm{TCR})$ are not fully understood, but existing evidence points towards both proinflammatory and suppressive functions as well as antigen-presenting and cytotoxic capacities [26-28]. In 2001, using an allogeneic rat model, Huang et al. showed that recipients of grafts depleted of $\gamma \delta \mathrm{TCR}^{+} \mathrm{T}$-cells had a higher incidence of acute GVHD than those transplanted with $\alpha \beta$ T-cell-depleted grafts [23]. It has also been shown that infusion of activated $\gamma \delta$ T-cells, in the absence of regular T-cells, can promote engraftment without causing GVHD in a MHC-mismatch situation [29]. Other animal studies have shown contradictory results, where $\gamma \delta$ T-cells appeared to be associated with an increased risk of GVHD [30, 31]. To date, only some clinical studies have addressed the issue of graft $\gamma \delta$ T-cell content in HSCT [32]. In a report that involved 63 recipients of unrelated peripheral blood stem cell grafts, Pabst et al. [19] found a correlation between high $\gamma \delta$ T-cell dose and higher incidence of acute GVHD of grades II-IV, while a more recent study has shown contradicting results in a smaller, more heterogeneous cohort of patients [33]. In our material, we found a lower frequency of naïve $\gamma \delta$ T-cells in the peripheral blood of donors corresponding to patients who later developed acute GVHD of grades II-IV (Figure 2(a)). There could be several possible reasons for the conflicting results. The timing of transfer of the $\gamma \delta$ T-cells in relation to the allograft has varied between studies. Secondly, if the $\gamma \delta$ T-cells exert their effect through direct or indirect interaction with other cell types, such as regulatory T-cells and $\alpha \beta$ T-cells [26, 27, 34, 35], differences in ratios between the infused doses of these cells might lead to different end-results. Lastly, the phenotype of $\gamma \delta$ T-cell subsets in the graft, particularly their activation and maturation status, could affect their function and ability to survive in vivo $[36,37]$.

Other minor lymphocyte populations that have attracted attention in the context of HSCT are T-cells expressing NKcell markers $[38,39]$. These can be either naturally occurring invariant NKT-cells or in vitro activated cytokine-induced killer (CIK) cells. Both cell subsets have been shown to have antitumour and tolerogenic abilities in preclinical studies [40-43]. Invariant NKT-cells have in several studies been shown to be able to reduce the risk for GVHD, whether they were present in high numbers in the graft or given through adoptive transfer $[24,44]$. Two independent clinical trials on the use of ex vivo expanded allogeneic CIK-cells, as part of treatment for relapsed haematological malignancies after HSCT, have shown response rates comparable to those for regular donor lymphocyte infusions (DLI), but with significantly lower incidence of GVHD [45, 46]. In the present study, we found significantly lower levels of T-cells expressing the NK-cell markers CD56 (on CD4 ${ }^{+}$T-cells) and CD94 (on naïve and terminally differentiated T-cells) in samples from donors before MLC in the GVHD group (Figure 2). If these cells correspond to previously described iNKT-cells, our study confirms that iNKT-cells may indeed have a GVHD-modulatory effect. The exact mechanism for this is not known, but experiments in murine models suggest that these cells have the ability to produce IL-4 and IFN$\gamma$ upon activation, which would help dampen the immune reaction behind GVHD $[25,47,48]$. Unfortunately, as no NKcell markers were included in the flow cytometry panel after MLC, it is difficult to speculate on CIK-cells in this study.

Activation-induced cell death (AICD) is important in the regulation of $\mathrm{T}$-cell responses and works as an inhibitory mechanism to prevent uncontrolled activation. AICD may be mediated through the interaction of CD95 (Fas) and CD95 ligand (FasL), which initiates the extrinsic pathway of programmed cell death $[49,50]$. The Fas-FasL interaction is of particular importance for establishing peripheral tolerance and it has been shown to have a role in attenuation of GVHD [51-54]. In our material, staining of unmanipulated donor PBMCs for CD95 revealed that samples from the GVHD group contained lower proportions of naïve T-cells that expressed this receptor on their surface (Figure 2(a)). Surface expression of CD95 is greatly increased on T-cells upon activation, while lower expression reflects a more naïve phenotype. This, together with other mechanisms, helps to protect cells from apoptosis in their resting state [55]. It is also in accordance with the widely accepted view that acute GVHD is induced by naive T-cells, most likely due to their ability to sustain a strong response $[56,57]$.

Different variations of the MLC have been used to assess the alloreactive capacity of donor cells in the setting of HLAidentical HSCTs, but the correlation to clinical results has varied. In particular, inconsistencies have been observed in matched unrelated transplantations [58-61]. The common principle for these methods is incubation of donor PBMCs with inactivated cells from the recipient followed by quantitative analysis of the helper T-lymphocyte precursor subset. Since these cells appeared to have a high propensity for producing IL-2, an assessment of proliferation and activity was obtained through coincubation with an IL-2-dependent cell line [59]. Multicolor flow cytometry is a more direct and specific approach for quantification and categorization of lymphocyte subpopulations after allogeneic MLC.

By using this sensitive technique, we could detect a shift in CD4/CD8 ratio after MLC between the patient groups. In the $5: 1$ setting, where the cells were exposed to alloantigen presentation, we could observe a trend for an increased proportion of $\mathrm{CD}^{+}{ }^{+} \mathrm{T}$-cells in the GVHD group as compared to the non-GVHD group. Moreover, this increased proportion of $\mathrm{CD}^{+}{ }^{+}$-cells in the GVHD group was also observed in 
the PHA setting (Figure 3(b)). It would therefore appear that, after stimulation, donor cells from the GVHD group tend to skew more to a $\mathrm{CD} 4{ }^{+} \mathrm{T}$-cell phenotype than donor cells from the non-GVHD group.

Additionally, we could detect a significant correlation between a decrease in the frequency of $\mathrm{CD} 9^{+} \mathrm{T}$-cells and incidence of acute GVHD grades II-IV even in this small material (Figure 3(c)). CD69 is traditionally seen as one of the earliest markers emerging after activation of T-cells, though it appears to also be highly expressed by lymphocytes at mucosal sites of the human body $[62,63]$. The counter-intuitive observation in the present study, that is, low frequency of activated T-cells correlating with GVHD, might be due to an increased downregulation of CD69 in alloreactive T-cells after 6 days of activation. CD69 is known to be transiently expressed, with an expression as early as 2 hours after stimulation, but with a quick decline of expression after more than 24 hours [64]. Thus, low levels of CD69 ${ }^{+}$ T-cells after MLC might serve as an indicator of increased alloreactivity and risk for incidence of acute GVHD.

It was surprising to find no differences in cytokine production between the patient groups. It is possible that the 6day MLC leads to a saturation of the system due to overstimulation. Periodic sampling during the MLC would have been elucidating. Additionally, the flow cytometry panel could be expanded to include more cellular markers to identify frequencies of other cellular populations that might play important roles in this context, such as regulatory T-cells, myeloid-derived suppressor cells (MDSCs), and mucosalassociated-invariant T-cells (MAITs). Recent studies suggest that these may play critical roles in GVHD development after HSCT and therefore warrant more extensive studies [65-69].

In conclusion, our results indicate that phenotypic analysis of the donor lymphocyte subpopulations before transplantation can yield predictive information of clinical relevance. We found a positive correlation between lower frequencies of donor T-cells expressing TCR $\gamma \delta$ and NK-cell markers on the one hand and incidence of acute GVHD of grades IIIV on the other hand. We have also shown that a distinct relative decrease in $\mathrm{CD} 69^{+} \mathrm{T}$-cells in a flow cytometry-based allogeneic MLC can be predictive of acute GVHD.

We recognise the fact that the sample groups in this pilot study are small and not perfectly matched for some clinical parameters, for example, diagnosis or conditioning regimen. Our results, therefore, need to be verified in a larger prospective trial. Nevertheless, the findings presented here may be of value in pretransplant risk assessment and they may enable the use of a more individualized prophylactic strategy.

\section{Competing Interests}

None of the authors has any potential financial conflict of interests related to this manuscript.

\section{Authors' Contributions}

Darius Sairafi and Arwen Stikvoort shared first authorship; these authors contributed equally.

\section{Acknowledgments}

The authors thank the Staff at the Centre for Allogeneic Stem Cell Transplantation for competent and compassionate care of the patients. This study was supported by grants from Swedish Research Council (K2012-64X-22020-01-3) and The Swedish Childhood Cancer Foundation (PROJ10/052).

\section{References}

[1] B. R. Blazar, W. J. Murphy, and M. Abedi, "Advances in graftversus-host disease biology and therapy," Nature Reviews Immunology, vol. 12, no. 6, pp. 443-458, 2012.

[2] B. E. Anderson, J. McNiff, J. Yan et al., "Memory CD4+ T cells do not induce graft-versus-host disease," Journal of Clinical Investigation, vol. 112, no. 1, pp. 101-108, 2003.

[3] W. Krenger, G. Falzarano, J. Delmonte Jr., K. M. Snyder, J. C. H. Byon, and J. L. M. Ferrara, "Interferon- $\gamma$ suppresses T-cell proliferation to mitogen via the nitric oxide pathway during experimental acute graft-versus-host disease," Blood, vol. 88, no. 3, pp. 1113-1121, 1996.

[4] J.-A. H. Young, "Infectious complications of acute and chronic GVHD," Best Practice \& Research: Clinical Haematology, vol. 21, no. 2, pp. 343-356, 2008.

[5] M. E. D. Flowers, Y. Inamoto, P. A. Carpenter et al., "Comparative analysis of risk factors for acute graft-versus-host disease and for chronic graft-versus-host disease according to National Institutes of Health consensus criteria," Blood, vol. 117, no. 11, pp. 3214-3219, 2011.

[6] L. Hambach, E. Spierings, and E. Goulmy, "Risk assessment in haematopoietic stem cell transplantation: minor histocompatibility antigens," Best Practice \& Research Clinical Haematology, vol. 20, no. 2, pp. 171-187, 2007.

[7] R. Marcn, "Immunosuppressive drugs in kidney transplantation: impact on patient survival, and incidence of cardiovascular disease, malignancy and infection," Drugs, vol. 69, no. 16, pp. 2227-2243, 2009.

[8] N. J. Chao and B. J. Chen, "Prophylaxis and treatment of acute graft-versus-host disease," Seminars in Hematology, vol. 43, no. 1, pp. 32-41, 2006.

[9] H. Glucksberg, R. Storb, A. Fefer et al., "Clinical manifestations of graft-versus-host disease in human recipients of marrow from HL-A-matched sibling donors,' Transplantation, vol. 18, no. 4, pp. 295-304, 1974.

[10] O. Olerup and H. Zetterquist, "HLA-DR typing by PCR amplification with sequence-specific primers (PCR-SSP) in 2 hours: an alternative to serological DR typing in clinical practice including donor-recipient matching in cadaveric transplantation," Tissue Antigens, vol. 39, no. 5, pp. 225-235, 1992.

[11] M. Okas, J. Gertow, M. Uzunel et al., "Clinical expansion of cord blood-derived T cells for use as donor lymphocyte infusion after cord blood transplantation," Journal of Immunotherapy, vol. 33, no. 1, pp. 96-105, 2010.

[12] M. Uhlin, E. Sandalova, M. G. Masucci, and V. Levitsky, "Help signals provided by lymphokines modulate the activation and apoptotic programs induced by partially agonistic peptides in specific cytotoxic T lymphocytes," European Journal of Immunology, vol. 35, no. 10, pp. 2929-2939, 2005.

[13] D. A. A. Vignali, "Multiplexed particle-based flow cytometric assays," Journal of Immunological Methods, vol. 243, no. 1-2, pp. 243-255, 2000. 
[14] E. Gorelik, D. P. Landsittel, A. M. Marrangoni et al., "Multiplexed immunobead-based cytokine profiling for early detection of ovarian cancer," Cancer Epidemiology Biomarkers and Prevention, vol. 14, no. 4, pp. 981-987, 2005.

[15] M. Lagrelius, P. Jones, K. Franck, and H. Gaines, "Cytokine detection by multiplex technology useful for assessing antigen specific cytokine profiles and kinetics in whole blood cultured up to seven days," Cytokine, vol. 33, no. 3, pp. 156-165, 2006.

[16] I. A. Wilson and R. L. Stanfield, "Unraveling the mysteries of $\gamma \delta$ T cell recognition,” Nature Immunology, vol. 2, no. 7, pp. 579581, 2001.

[17] Y. C. Linn and K. M. Hui, "Cytokine-induced NK-like T cells: from bench to bedside," Journal of Biomedicine and Biotechnology, vol. 2010, Article ID 435745, 8 pages, 2010.

[18] A. P. Iori, G. F. Torelli, M. S. De Propris et al., "B-cell concentration in the apheretic product predicts acute graft-versus-host disease and treatment-related mortality of allogeneic peripheral blood stem cell transplantation," Transplantation, vol. 85, no. 3 , pp. 386-390, 2008.

[19] C. Pabst, H. Schirutschke, G. Ehninger, M. Bornhäuser, and U. Platzbecker, "The graft content of donor T cells expressing $\gamma \delta \mathrm{TCR}+$ and $\mathrm{CD} 4+\mathrm{foxp} 3+$ predicts the risk of acute graft versus host disease after transplantation of allogeneic peripheral blood stem cells from unrelated donors," Clinical Cancer Research, vol. 13, no. 10, pp. 2916-2922, 2007.

[20] J. Vela-Ojeda, M. A. García-Ruiz Esparza, E. Reyes-Maldonado et al., "Clinical relevance of NK, NKT, and dendritic cell dose in patients receiving G-CSF-mobilized peripheral blood allogeneic stem cell transplantation," Annals of Hematology, vol. 85, no. 2, pp. 113-120, 2006.

[21] J. P. Panse, S. Heimfeld, K. A. Guthrie et al., "Allogeneic peripheral blood stem cell graft composition affects early T-cell chimaerism and later clinical outcomes after non-myeloablative conditioning," British Journal of Haematology, vol. 128, no. 5, pp. 659-667, 2005.

[22] S. Yamasaki, H. Henzan, Y. Ohno et al., "Influence of transplanted dose of CD56+ cells on development of graft-versushost disease in patients receiving G-CSF-mobilized peripheral blood progenitor cells from HLA-identical sibling donors," Bone Marrow Transplantation, vol. 32, no. 5, pp. 505-510, 2003.

[23] Y. Huang, D. E. Cramer, M. B. Ray, P. M. Chilton, X. Que, and S. T. Ildstad, "The role of $\alpha \beta$ - and $\gamma \delta$-T cells in allogeneic donor marrow on engraftment, chimerism, and graft-versus-host disease," Transplantation, vol. 72, no. 12, pp. 1907-1914, 2001.

[24] A. Chaidos, S. Patterson, R. Szydlo et al., "Graft invariant natural killer T-cell dose predicts risk of acute graft-versus-host disease in allogeneic hematopoietic stem cell transplantation," Blood, vol. 119, no. 21, pp. 5030-5036, 2012.

[25] D. B. Leveson-Gower, J. A. Olson, E. I. Sega et al., "Low doses of natural killer T cells provide protection from acute graft-versushost disease via an IL-4-dependent mechanism," Blood, vol. 117, no. 11, pp. 3220-3229, 2011.

[26] M. Brandes, K. Willimann, G. Bioley et al., "Cross-presenting human $\gamma \delta$ T cells induce robust CD $8+\alpha \beta$ T cell responses," Proceedings of the National Academy of Sciences of the United States of America, vol. 106, no. 7, pp. 2307-2312, 2009.

[27] R. Casetti, C. Agrati, M. Wallace et al., "Cutting edge: TGF- $\beta 1$ and IL-15 induce FOXP $3^{+} \gamma \delta$ regulatory T cells in the presence of antigen stimulation," The Journal of Immunology, vol. 183, no. 6, pp. 3574-3577, 2009.

[28] R. D. Lopez, S. Xu, B. Guo, R. S. Negrin, and E. K. Waller, “CD2mediated IL-12-dependent signals render human $\gamma \delta$-T cells resistant to mitogen-induced apoptosis, permitting the largescale ex vivo expansion of functionally distinct lymphocytes: implications for the development of adoptive immunotherapy strategies," Blood, vol. 96, no. 12, pp. 3827-3837, 2000.

[29] W. R. Drobyski, D. Majewski, and G. Hanson, "Graft-facilitating doses of ex vivo activated $\gamma \delta$ T cells do not cause lethal murine graft-vs.-host disease," Biology of Blood and Marrow Transplantation, vol. 5, no. 4, pp. 222-230, 1999.

[30] B. R. Blazar, P. A. Taylor, A. Panoskaltsis-Mortari et al., "Lethal murine graft-versus-host disease induced by donor gamma/ delta expressing $\mathrm{T}$ cells with specificity for host nonclassical major histocompatibility complex class Ib antigens," Blood, vol. 87, pp. 827-837, 1996.

[31] Y. Maeda, P. Reddy, K. P. Lowler, C. Liu, D. K. Bishop, and J. L. M. Ferrara, "Critical role of host $\gamma \delta$ T cells in experimental acute graft-versus-host disease," Blood, vol. 106, no. 2, pp. 749-755, 2005.

[32] L. S. Lamb Jr. and R. D. Lopez, " $\gamma \delta$ T cells: a new frontier for immunotherapy," Biology of Blood and Marrow Transplantation, vol. 11, no. 3, pp. 161-168, 2005.

[33] N. Watanabe, M. Narita, T. Furukawa et al., "Kinetics of pDCs, $\mathrm{mDCs}, \gamma \delta \mathrm{T}$ cells and regulatory T cells in association with graft versus host disease after hematopoietic stem cell transplantation," International Journal of Laboratory Hematology, vol. 33, no. 4, pp. 378-390, 2011.

[34] S. Tsuji, D. Char, R. P. Bucy, M. Simonsen, C.-L. H. Chen, and M. D. Cooper, " $\gamma \delta$ T cells are secondary participants in acute graftversus-host reactions initiated by CD $4+\alpha \beta$ T cells," European Journal of Immunology, vol. 26, no. 2, pp. 420-427, 1996.

[35] A. Mukasa, K. Hiromatsu, G. Matsuzaki, R. O’Brien, W. Born, and K. Nomoto, "Bacterial infection of the testis leading to autoaggressive immunity triggers apparently opposed responses of $\alpha \beta$ and $\gamma \delta$ T cells," Journal of Immunology, vol. 155, no. 4, pp. 2047-2056, 1995.

[36] F. Dieli, F. Poccia, M. Lipp et al., "Differentiation of effector/memory $\mathrm{V} \delta 2 \mathrm{~T}$ cells and migratory routes in lymph nodes or inflammatory sites," The Journal of Experimental Medicine, vol. 198, no. 3, pp. 391-397, 2003.

[37] K. D. Jensen and Y.-H. Chien, "Thymic maturation determines $\gamma \delta$ T cell function, but not their antigen specificities," Current Opinion in Immunology, vol. 21, no. 2, pp. 140-145, 2009.

[38] M. Sykes, "Unusual T cell populations in adult murine bone marrow. Prevalence of CD3+CD4-CD8- and alpha beta TCR+NK1.1+ cells," The Journal of Immunology, vol. 145, no. 10, pp. 3209-3215, 1990.

[39] R. E. Schmidt, C. Murray, J. F. Daley, S. F. Schlossman, and J. Ritz, "A subset of natural killer cells in peripheral blood displays a mature T cell phenotype," The Journal of Experimental Medicine, vol. 164, no. 1, pp. 351-356, 1986.

[40] I. G. H. Schmidt-Wolf, R. S. Negrin, H.-P. Kiem, K. G. Blume, and I. L. Weissman, "Use of a SCID mouse/human lymphoma model to evaluate cytokine-induced killer cells with potent antitumor cell activity," The Journal of Experimental Medicine, vol. 174, no. 1, pp. 139-149, 1991.

[41] P. M. Anderson, B. R. Blazar, F. H. Bach, and A. C. Ochoa, "AntiCD3 + IL-2-stimulated murine killer cells. In vitro generation and in vivo antitumor activity," Journal of Immunology, vol. 142, no. 4, pp. 1383-1394, 1989.

[42] M. Higuchi, D. Zeng, J. Shizuru et al., "Immune tolerance to combined organ and bone marrow transplants after fractionated lymphoid irradiation involves regulatory NK T cells and 
clonal deletion," Journal of Immunology, vol. 169, no. 10, pp. 5564-5570, 2002.

[43] J. Baker, M. R. Verneris, M. Ito, J. A. Shizuru, and R. S. Negrin, "Expansion of cytolytic $\mathrm{CD}^{+}$natural killer T cells with limited capacity for graft-versus-host disease induction due to interferon $\gamma$ production," Blood, vol. 97, no. 10, pp. 2923-2931, 2001.

[44] D. Schneidawind, J. Baker, A. Pierini et al., "Third-party CD $4^{+}$ invariant natural killer $\mathrm{T}$ cells protect from murine GVHD lethality," Blood, vol. 125, no. 22, pp. 3491-3500, 2015.

[45] M. Introna, G. Borleri, E. Conti et al., "Repeated infusions of donor-derived cytokine-induced killer cells in patients relapsing after allogeneic stem cell transplantation: A Phase I Study," Haematologica, vol. 92, no. 7, pp. 952-959, 2007.

[46] G. G. Laport, K. Sheehan, J. Baker et al., "Adoptive immunotherapy with cytokine-induced killer cells for patients with relapsed hematologic malignancies after allogeneic hematopoietic cell transplantation," Biology of Blood and Marrow Transplantation, vol. 17, no. 11, pp. 1679-1687, 2011.

[47] J. H. Kim, E. Y. Choi, and D. H. Chung, "Donor bone marrow type II (non-V $\alpha 14 \mathrm{~J} \alpha 18 \mathrm{CD} 1 \mathrm{~d}-$ restricted) NKT cells suppress graft-versus-host disease by producing IFN- $\gamma$ and IL- 4 ," The Journal of Immunology, vol. 179, no. 10, pp. 6579-6587, 2007.

[48] H. Chen and W. E. Paul, "Cultured NK1.1+ CD4+ T cells produce large amounts of IL-4 and IFN-gamma upon activation by anti-CD3 or CD1," The Journal of Immunology, vol. 159, no. 5, pp. 2240-2249, 1997.

[49] P. Bouillet and L. A. O'Reilly, "CD95, BIM and T cell homeostasis," Nature Reviews Immunology, vol. 9, no. 7, pp. 514-519, 2009.

[50] C. Kurts, W. R. Heath, H. Kosaka, J. F. A. P. Miller, and F. R. Carbone, "The peripheral deletion of autoreactive CD8+ T cells induced by cross- presentation of self-antigens involves signaling through CD95 (Fas, Apo-1)," The Journal of Experimental Medicine, vol. 188, no. 2, pp. 415-420, 1998.

[51] M. R. Alderson, T. W. Tough, T. Davis-Smith et al., "Fas ligand mediates activation-induced cell death in human T lymphocytes," The Journal of Experimental Medicine, vol. 181, no. 1, pp. 71-77, 1995.

[52] J. Dhein, H. Walczak, C. Bäumler, K.-M. Debatin, and P. H. Krammer, "Autocrine T-cell suicide mediated by APO-1/(Fas/ CD95)," Nature, vol. 373, no. 6513, pp. 438-441, 1995.

[53] C. S. Via, P. Nguyen, A. Shustov, J. Drappa, and K. B. Elkon, "A major role for the Fas pathway in acute graft-versus-host disease," The Journal of Immunology, vol. 157, no. 12, pp. 53875393, 1996.

[54] O. Bohana-Kashtan, S. Morisot, R. Hildreth, C. Brayton, H. I. Levitsky, and C. I. Civin, "Selective reduction of graft-versushost disease-mediating human $\mathrm{T}$ cells by ex vivo treatment with soluble Fas ligand," Journal of Immunology, vol. 183, no. 1, pp. 696-705, 2009.

[55] J. H. Russell, C. L. White, D. Y. Loh, and P. Meleedy-Rey, "Receptor-stimulated death pathway is opened by antigen in mature T cells," Proceedings of the National Academy of Sciences of the United States of America, vol. 88, no. 6, pp. 2151-2155, 1991.

[56] A. Beilhack, S. Schulz, J. Baker et al., "In vivo analyses of early events in acute graft-versus-host disease reveal sequential infiltration of T-cell subsets," Blood, vol. 106, no. 3, pp. 1113-1122, 2005.

[57] H. Zheng, C. Matte-Martone, H. Li et al., "Effector memory $\mathrm{CD} 4^{+} \mathrm{T}$ cells mediate graft-versus-leukemia without inducing graft-versus-host disease," Blood, vol. 111, no. 4, pp. 2476-2484, 2008.
[58] G. C. DeGast, E. M. Mickelson, P. G. Beatty et al., "Mixed leukocyte culture reactivity and graft-versus-host disease in HLA-identical marrow transplantation for leukemia," Bone Marrow Transplantation, vol. 9, no. 2, pp. 87-90, 1992.

[59] A. P. Schwarer, Y. Z. Jiang, A. J. Barrett et al., "Frequency of antirecipient alloreactive helper T-cell precursors in donor blood and graft-versus-host disease after HLA-identical sibling bonemarrow transplantation," The Lancet, vol. 341, no. 8839, pp. $203-$ 205, 1993.

[60] M. Theobald, T. Nierle, D. Bunjes, R. Arnold, and H. Heimpel, "Host-specific interleukin-2-secreting donor T-cell precursors as predictors of acute graft-versus-host disease in bone marrow transplantation between HLA-identical siblings," The New England Journal of Medicine, vol. 327, no. 23, pp. 1613-1617, 1992.

[61] G. Healey and A. P. Schwarer, "The helper T lymphocyte precursor (HTLp) frequency does not predict outcome after HLAidentical sibling donor G-CSF-mobilised peripheral blood stem cell transplantation," Bone Marrow Transplantation, vol. 30, no. 6, pp. 341-346, 2002.

[62] M. López-Cabrera, A. G. Santis, E. Fernández-Ruiz et al., "Molecular cloning, expression, and chromosomal localization of the human earliest lymphocyte activation antigen AIM/ CD69, a new member of the C-type animal lectin superfamily of signal-transmitting receptors," Journal of Experimental Medicine, vol. 178, no. 2, pp. 537-547, 1993.

[63] K. Radulovic and J. H. Niess, "CD69 is the crucial regulator of intestinal inflammation: a new target molecule for IBD treatment?" Journal of Immunology Research, vol. 2015, Article ID 497056, 12 pages, 2015.

[64] R. Testi, D. D’Ambrosio, R. De Maria, and A. Santoni, “The CD69 receptor: a multipurpose cell-surface trigger for hematopoietic cells," Immunology Today, vol. 15, no. 10, pp. 479-483, 1994.

[65] A. Vendramin, S. Gimondi, A. Bermema et al., "Graft monocytic myeloid-derived suppressor cell content predicts the risk of acute graft-versus-host disease after allogeneic transplantation of granulocyte colony-stimulating factor-mobilized peripheral blood stem cells," Biology of Blood and Marrow Transplantation, vol. 20, no. 12, pp. 2049-2055, 2014.

[66] J. J. Messmann, T. Reisser, F. Leithäuser, M. B. Lutz, K.-M. Debatin, and G. Strauss, "In vitro-generated MDSCs prevent murine GVHD by inducing type $2 \mathrm{~T}$ cells without disabling antitumor cytotoxicity," Blood, vol. 126, no. 9, pp. 1138-1148, 2015.

[67] A. Pierini, L. Colonna, M. Alvarez et al., "Donor requirements for regulatory $\mathrm{T}$ cell suppression of murine graft-versus-host disease," Journal of Immunology, vol. 195, no. 1, pp. 347-355, 2015.

[68] D. Schneidawind, A. Pierini, M. Alvarez et al., "CD41 invariant natural killer $\mathrm{T}$ cells protect from murine GVHD lethality through expansion of donor CD41CD251FoxP31 regulatory $\mathrm{T}$ cells," Blood, vol. 124, no. 22, pp. 3320-3328, 2014.

[69] B. S. Kim, H. Nishikii, J. Baker et al., "Treatment with agonistic DR3 antibody results in expansion of donor Tregs and reduced graft-versus-host disease," Blood, vol. 126, no. 4, pp. 546-557, 2015. 


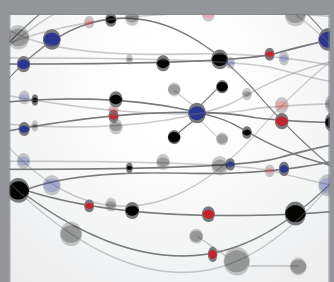

The Scientific World Journal
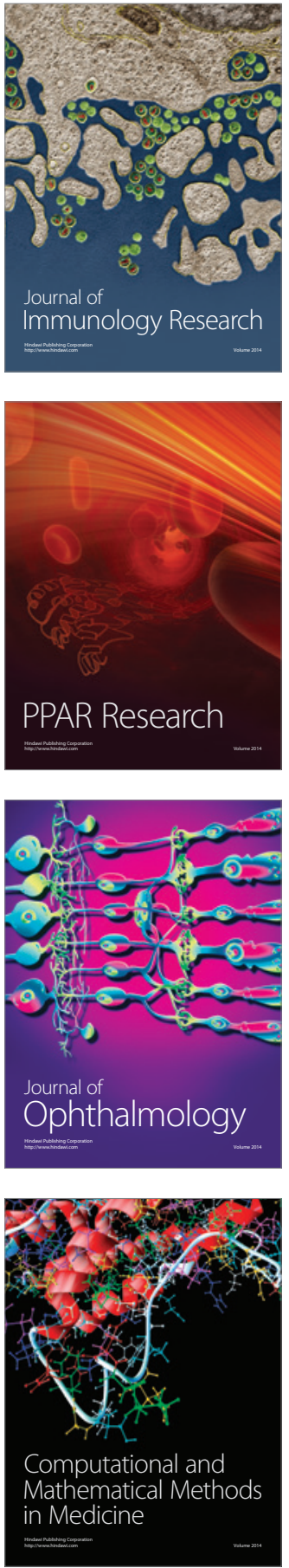

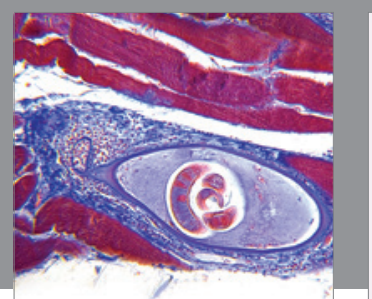

Gastroenterology Research and Practice

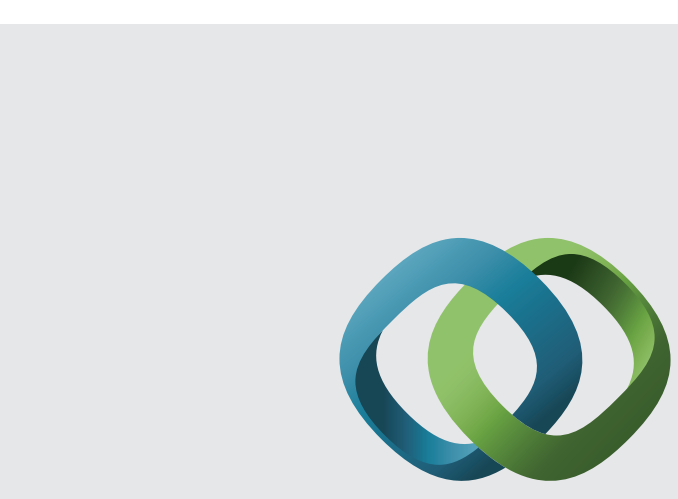

\section{Hindawi}

Submit your manuscripts at

http://www.hindawi.com
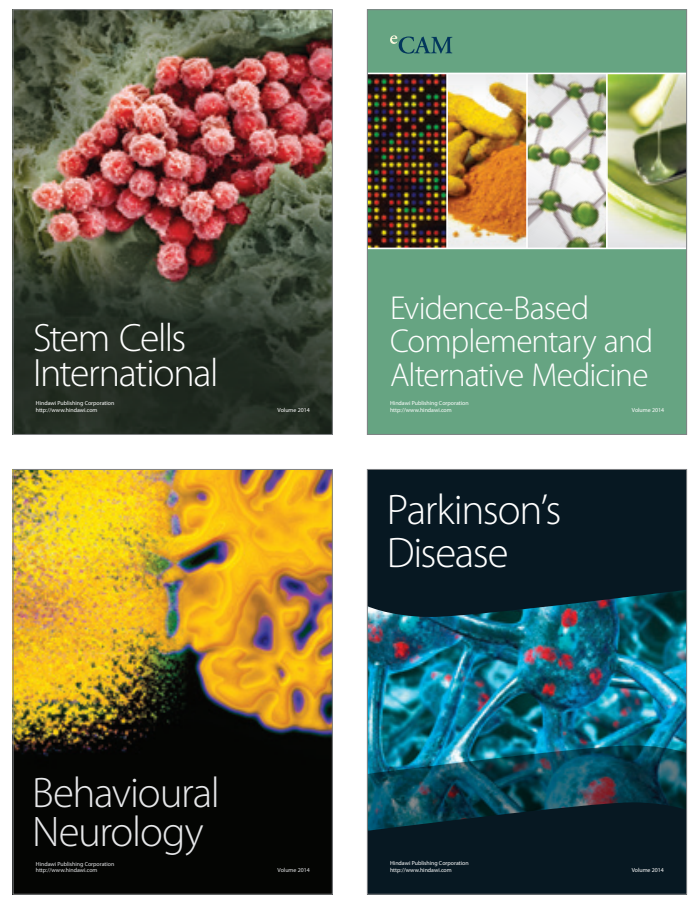
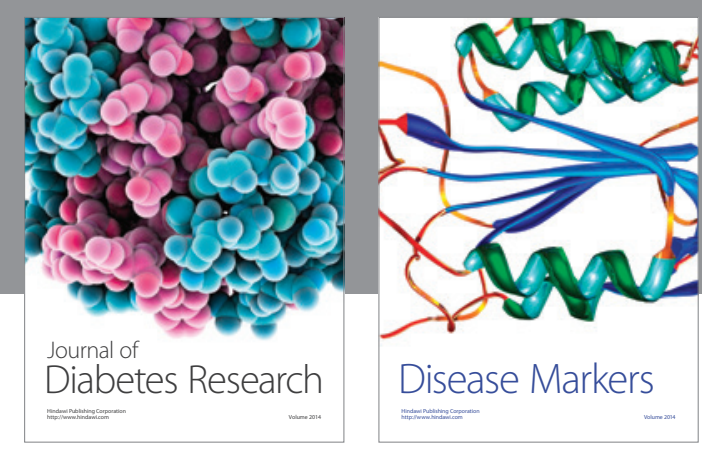

Disease Markers
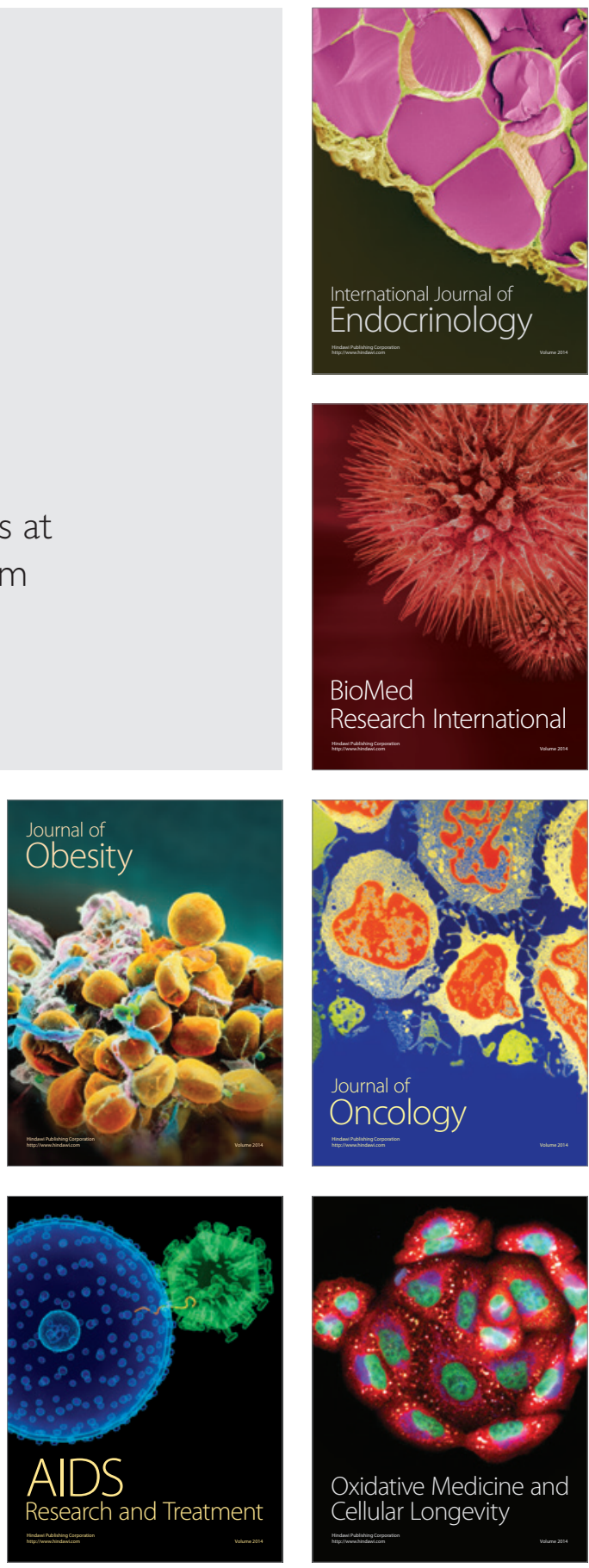